\title{
Social Responsibility in the Operation of Central Banks*
}

\author{
Csaba Lentner - Krisztina Szegedi - Tibor Tatay
}

In our study, we set out from the hypothesis that the social responsibility of central banks is peculiar, since these were established decidedly for the benefit of the common good. For the interpretation of their social responsibility, we first examine the concept of corporate social responsibility (CSR) in corporate practice. After this, we transpose the interpretation of CSR, applied to the operation of central banks. We interpret the concept of economic, legal, ethical and philanthropic responsibility in connection with the activity of central banks. Using examples, we shed light on how we specifically interpret the individual components of corporate social responsibility in the central bank practice, via the activity of the Magyar Nemzeti Bank, the US Federal Reserve, the European Central Bank, and the central banks of the Netherlands, Denmark, Spain, Poland and the Czech Republic.

Journal of Economic Literature (JEL) codes: M14, E58 E44, G28

Keywords: corporate social responsibility, CSR, central bank, public awareness, financial stability, business ethics, central bank

\section{Introduction}

After the 2008 crisis, crisis management required that central banks modify their previous monetary policy mindset based on neoliberal economic views. As an effect of the circumstances, it seems that the monetary policy practice of the leading central banks changes permanently. According to Akerlof and Shiller (2011), the most destructive effect of the crisis is that there is lack of confidence in the participants of the economy regarding the future. In 2008, the initial freeze-up of the financial markets resulted from banks' shaken confidence in each other. After the disappearance of liquidity, mistrust later spread further to the other economic participants as well. Public confidence was undermined in connection with money

* The views expressed in this paper are those of the author(s) and do not necessarily reflect the offical view of the Magyar Nemzeti Bank.

Csaba Lentner is professor and head of department at the Department of Public Finances of the National University of Public Service. E-mail: Lentner.Csaba@uni-nke.hu.

Krisztina Szegedi is associate professor at the Institute of Business Economics of the University of Miskolc. E-mail:vgtkrisz@uni-miskolc.hu.

Tibor Tatay is associate professor at the Department of Economic Analyses of the Széchenyi István University. E-mail: tatay@sze.hu.

The manuscript was received on 22 December 2016.

DOI: http://doi.org/10.25201/FER.16.2.6485 
and the money creation processes of central banks. Analysing this process, Braun (2016) called attention to how far the folk theory of money is from how money actually works. Recognising this, the fellow workers of the British central bank (Jakab-Kumhof 2015), the Dutch central bank (De Nederlandsche Bank 2016), and the Magyar Nemzeti Bank (Ábel-Lehman-Tapaszti 2016) attempted to dispel the doubts, clarifying the widespread mistakes, with their articles, in order to maintain the authenticity of central banks (Braun 2016:1084).

The behaviour of the financial sector has not changed fundamentally since the crisis: short-term profit is still at the forefront, instead of long-term prudence. It is necessary to return to the essential question of how the financial sector can serve the welfare of society. Financial stability is essential for this. In order to restore confidence, changing behaviour and culture, integrity, transparency, strengthening of the ethical dimension, and assuming corporate responsibility are necessary as the fundamental criteria of financial stability (Lagarde 2014).

It is a social expectation that the culture of the financial institutional system be transformed. Changing the central bank mentality must assist in this transformation of financial organisational culture (Shirakawa 2010). In changing this mentality, the short-term objectives characterising the period before 2008 are replaced by objectives focusing on the medium and long term, and at the same time the search for new roles can be observed at central banks (Pesuth 2016). The new roles can stem from the changes in the tasks of central banks stipulated in legal regulations. Rephrasing the roles can be voluntary, implemented by rearranging the focal points of the tasks set under the previous framework of legal regulations.

It now appears that central banks also see the implementation of their tasks in a framework which is different from their monetary policy thinking prior to 2008. The focus on ensuring financial stability has changed the role of central banks as well. In addition to the traditional monetary control tasks, their mandate includes the task of supervising and regulating the financial sector as well. Since the outbreak of the crisis, supporting economic growth has also received a greater role, in addition to uninterrupted financial stability as a new mandate. Expansion of the mandate has also made it necessary to broaden the set of instruments (Ábel et al. 2014). At the same time, the question has arisen as to what approaches should be applied for the successful fulfilment of the multiple mandates. Another question is how the changed role and new expectations can be fulfilled with efficient organisational behaviour and a guidance culture adjusting to these changes (Kahn 2016).

In the decision-making and implementation of tasks, it is necessary to pay more attention to the social impacts. A stronger focus on social responsibility has already been part of the corporate sector (primarily by large enterprises) for quite some time. This approach has also taken root in the banking sector, and to a certain extent in the organisational operation of central banks as well. In the following, we 
summarise the concept and development of the CSR approach and way of thinking, and its interpretation for central banks. This topic was already examined in our earlier research (Lentner et al. 2015); in this article, we rephrase - supplement and update - our previous thoughts.

\section{Concept of corporate social responsibility (CSR)}

Significant advances in the concept of corporate social responsibility (CSR) have been seen in recent decades, both in terms of theory and corporate practice (Szegedi 2014). The current CSR approaches extend well beyond the early interpretation of the concept, when it arose in connection with managers that they not only had economic responsibility vis-à-vis the owners, but also social responsibility vis-à-vis society as well (Dodd 1932:1149). There are several versions of CSR definitions, of which Dahlsrud (2008) distinguished five main dimensions, analysing in detail almost forty CSR definitions:

1. Environmental dimension - keywords: cleaner environment, environmental stewardship, environmental concerns in business operations;

2. Social dimension - keywords: contribute to a better society, integrate social concerns in business operations, positive and negative impact of companies on society and communities;

3. Economic dimension - keywords: contribute to economic development, longterm profitability

4. Stakeholder dimension - keywords: relations with stakeholders, dialogue with stakeholders, involving stakeholders;

5. Voluntariness dimension - keywords: voluntary actions beyond legal obligations.

As shown in the list, the economic, social and environmental pillars of sustainable development appear in the CSR definitions, supplemented with the stakeholder approach and the voluntariness dimension. The stakeholder approach has typically appeared in connection with the corporate sphere. To the question why we should listen to stakeholders, the answer is ethical obligation, as it was deduced by Evan and Freeman (1988) in connection with the stakeholder theory. The connection between the CRS model and the stakeholder approach is important, because the latter names the parties vis-à-vis whom the company undertakes responsibility, and - according to one of the best known and most accepted definitions of CSR - this comprises economic, legal, ethical and philanthropic responsibility (Carroll 1979:500). In terms of responsibility, it is not the strength of the stakeholders that is important, but their legitimacy (Carroll 1991). Table 1 summarises the four areas of responsibility of CSR, building on each other. 


\begin{tabular}{|c|c|}
\hline \multicolumn{2}{|c|}{$\begin{array}{l}\text { Table } 1 \\
\text { Areas of corporate social responsibility }\end{array}$} \\
\hline Area of responsibility & Contents of responsibility \\
\hline Economic responsibility & $\begin{array}{l}\text { Includes the maximisation of earnings per share, maximisation of profit, } \\
\text { strong competitive position, high level of operating efficiency, and long-term } \\
\text { profitability. }\end{array}$ \\
\hline Legal responsibility & $\begin{array}{l}\text { The company must meet its economic responsibility within the legal } \\
\text { frameworks. This means compliance with laws, legal regulations and local } \\
\text { regulations; moreover, that the company is defined as a law-abiding } \\
\text { corporate citizen, and its goods and services should comply with the legal } \\
\text { requirements. }\end{array}$ \\
\hline Ethical responsibility & $\begin{array}{l}\text { It means the compliance of norms and requirements that go beyond legal } \\
\text { responsibility and are not included in legal regulations. With respect to } \\
\text { customers, employees, owners and communities, these reflect honest and } \\
\text { fair behaviour protecting and respecting the moral requirements of } \\
\text { stakeholders. }\end{array}$ \\
\hline $\begin{array}{l}\text { Philanthropic } \\
\text { responsibility }\end{array}$ & $\begin{array}{l}\text { The companies contribute to enhancing welfare and the quality of life as } \\
\text { good corporate citizens, for example with the support of the arts, education } \\
\text { or community with voluntary activities. These are of discretionary and } \\
\text { voluntary nature. }\end{array}$ \\
\hline
\end{tabular}

The theoretical experts dealing with the operation of companies also agree, in general, that companies must behave responsibly, in an ethical manner, but there is a question of how this can be implemented in practice and how it affects the economic performance of companies (Chikán 2003). In connection with the economic benefits of corporate social responsibility, Kurucz, Colbert and Wheeler (2008) have shown that this can be deducted from the decrease in costs and risks, competitive advantages, increases in reputation and legitimacy, and value creation stemming from win-win type situations. Margolis, Elfenbeien and Walsh (2009) analysed 167 empirical studies from the past 35 years and established a positive connection between CSR and financial results, on the basis of philanthropic contributions, explored abuses and transparent operations. According to the recommendation of Carroll and Shabana (2010), this connection must be handled in a complex manner, and the support of stakeholders is also necessary for the positive connection. CSR is an ethical obligation of companies, irrespective of whether it can be recovered economically or not. At the same time, the rising expectations of corporate stakeholders of such a nature and the market recognition of responsible companies increasingly result in the recovery of CSR, which moves the integration of the approach into practice in a positive direction.

According to Archie Carroll (2015a), the researcher who received the Lifetime Achievement Award in CSR in 2012, the concepts of corporate citizenship, business ethics, stakeholder management, sustainability and creating shared value are competing versions of corporate social responsibility, and attempts are made to consider one as a part of the other or many people already use these as synonyms, 
and this trend will strengthen in the future. In corporate practice, the approach of sustainability is attractive, since it is rather neutral and it expresses positive contribution related to the future, while corporate social responsibility urges responsibility in the present as well, whereas business ethics is less popular because of its critical approach (Carroll 2015b). Just as sustainable development requires a fundamental shift in attitudes (Kerekes 2009), corporate social responsibility also presses for changes to the business model.

In practice, however, at most companies, we find charitable events in connection with CSR and increasing the efficiency of operation appears as an objective at a significant portion of these, but the requirement of true transformation of the business model only is perceptible at a small part of companies (Rangan et al. 2015). With its approach of transforming the business model, corporate social responsibility addresses the concept of social enterprise, which aims for the solution of a social problem, in addition to economic sustainability. The concept of sustainable development suggests that each enterprise must be a social enterprise at the same time, and vice versa, creating harmony among economic, environmental and social objectives, and thereby contributing to sustainable development.

\section{Interpretation of the elements of CSR in connection with central banks}

The social responsibility of central banks has arisen especially regarding the last crisis. The American central bank made extraordinary efforts to handle the crisis and save the financial system, in order to avoid a global financial collapse. The responsibility of central banks is significant not only in terms of direct measures, but also in connection with the subsequent regulation (Schoen 2016). The social responsibility of central banks is peculiar, as these were established specifically for the benefit of the common good. Their objectives and tasks are stipulated in legal regulations. Thus, central banks are institutions promoting the achievement of specific economic policy objectives. According to their tasks, they are organisations performing state authority tasks as well. Therefore, the social responsibility formulated by Carroll (1991) can only be interpreted in a modified form in this sphere.

Naturally, the specific elements of CSR appear in various forms at the individual central banks. The regulatory environment, mandate and scope of the individual central banks are different. After the 2008 crisis there were problems which had to be handled similarly, such as the management of macro-prudential risks, but there were also problems to be treated in completely different ways. For example, the treatment of stability risks related to foreign exchange loans in Hungary was unique. Hence, in the following we would like to shed light on the elements of social responsibility and the acceptance of the approach on the basis of the practices of individual central banks. 


\subsection{Economic responsibility of central banks}

The economic responsibility of central banks differs from the profit maximisation valid for business enterprises, but the concepts of a high level of operating efficiency and long-term success can be interpreted, taking into account the restrictions of legal regulations. The economic responsibility of the central bank is unique, as its objectives are macroeconomy-level economic policy objectives, and its tasks are special tasks stipulated in legal regulations.

In the case of the Magyar Nemzeti Bank (MNB), Lentner et al. (2015:28) summarised this characteristic supported with statements highlighted from the legal regulations: "The primary objective of the MNB shall be to achieve and maintain price stability. Without endangering its primary objective, it shall support the maintenance of stability of the financial intermediary system and the increase of its resilience. It shall support the sustainable contribution of the financial intermediary system to economic growth. It shall support the economic policy of the government with the instruments available to it."

Within the scope of fundamental tasks stipulated in the MNB Act, it determines and implements monetary policy. MNB is entitled to issue the legal tender of Hungary. "In the interest of maintaining the external stability of the Hungarian economy, it shall form and manage official foreign exchange and gold reserves, it shall perform foreign exchange transactions, and it shall supervise the payment, settlement and security settlement systems" (Lentner et al. 2015:39). In order to perform its tasks and in the sphere of data reporting obligation existing to the ECB, "it shall collect and disclose statistical information". The MNB "shall establish the macro-prudential policy for the stability of the entire system of financial intermediation", with the objective to enhance the resilience of the system of financial intermediation and to ensure its sustainable contribution to economic growth. To this end, the "MNB shall explore the business and economic risks threatening the system of financial intermediation as a whole, it shall promote the prevention of the development of systemic risks and the reduction or elimination of the evolved systemic risks; furthermore, in the event of disturbances to the credit market it shall contribute to the balanced functioning of the system of intermediation in financing the economy through stimulating lending and - in the event of excessive credit outflow - by restraining lending. The MNB shall fulfil the role of a resolution authority. Moreover, it shall perform the supervision of the system of financial intermediation and it shall ensure the undisturbed operation of that. It shall protect the interests of parties using financial services" in order to increase public confidence (MNB Act 2013, Lentner et al. 2015:39).

Despite the restrictions of the legal regulations, the central bank has a large room for manoeuvre in implementing its objectives. Due to the exclusive focus on the price stability objective between 2001 and 2013, the other possible objectives of the MNB for supporting the economy were relegated. This was similar to the policy 
of the leading central banks established from the 1990s. Since 2013, the MNB has reinterpreted its economic role (Matolcsy 2015). In accordance with its core task stipulated in the Act (MNB Act 2013), it played a role in the conversion of foreign currency household loans into forint, the stimulus of corporate lending, and the promotion of financing the state. The conversion of foreign currency household loans into forint helped to increase the stability of the banking system and resolve the uncertain position of households. Stimulating the lending activity of banks to enterprises took the form of the funding for growth scheme, and then the market-based lending scheme. The central bank has set the objective of promoting economic growth by supporting lending. The objective of the self-financing programme, started in 2014, was to support the obtaining of cheaper funds of the state from the market. Between 2002 and 2010 the significantly increased government debt and the high exposure of foreign exchange within government debt made Hungary vulnerable. These factors made debt financing significantly more expensive. With the self-financing programme, the MNB aimed at decreasing the ratio of foreign exchange debt within the overall debt, increasing financing in forint and achieving a greater role of domestic participants in this financing.

After the 2008 financial crisis, there were also changes in the responsibilities and objectives of the leading central banks. The immediate management of the crisis and then the mitigation of the consequences required the utilisation of significant state funds from the governments as well. In order to avoid the subsequent assistance of financial institutions using state funds, the task of financial stability was emphasised strongly among the objectives of the central banks, in addition to the objective of maintaining price stability. The task of maintenance of financial stability was rephrased as a task of the central bank in the United States, but the European Central Bank can also be mentioned as an example in this sphere (Neményi 2012).

The crisis directed the attention to the importance of the stabilising role of central banks all over the world. The European Central Bank initiated comprehensive examinations in the European banking system. Significant resources were deployed by the Fed for controlling financial stability, and the macro-prudential approach has become an important accessory in the instruments assisting a healthy economy (Yellen 2014). The extraordinary liquidity measures by the European Central Bank tangibly decreased financial market tensions (Szczerbowicz 2015). Legislators expanded the tasks of central banks all over the world, and the decision-makers of central banks also reassessed the economic role of their institutions. Since 2008, central banks have utilised non-standard instruments to restore global growth (Sági 2010).

The innovative measures that became necessary because of the financial crisis can be described with the expression "reliable vigilance" at the European Central Bank. The crisis was the symptom of the exaggerations and imbalances that accumulated in the decade before 2008 at households, enterprises and financial institutions, 
especially the accumulation of debt and risk, and rising capital gearing. Although the quick state measures mitigated these, the crisis still resulted in another disturbance: the rapid increase in government debt. The standard and non-standard instruments of monetary policy decision-making reflected the fundamental conviction and responsibility of the decision-makers. The task of central banks is to ensure stability. From the economic processes of the past thirty years, the ECB learned that actions must occur in a predictable manner which is comprehensible for the affected parties, in a framework consistent with the objective of price stability. However, a balance between predictability and flexibility which is necessary under unexpected circumstances also has to be found. In the extraordinary period of the crisis, the non-standard instruments used by the central banks had less predictable effects, based on their very nature. The global environment, in which decisions have to be made, is characterised by significant complexity and uncertainty, and thus quick measures may be necessary in the future as well. It is very important that an attempt must be made at crisis prevention rather than crisis management. This often requires measures that are more difficult to understand for outsiders. The utilisation of standard and non-standard instruments raises the ethical approach of obligation and consequence. Under normal circumstances, compliance with norms may work well, but under unusual circumstances, these cannot always be complied with, and instead the consideration of the consequences of the decisions and the responsibility for these come to the fore. Both approaches must be present at the same time in the operation of central banks (Trichet 2010).

\section{Table 2}

Objectives of the Fed for supervision, regulation and financial stability

\begin{tabular}{l|l}
\multicolumn{1}{c|}{ Objective } & \multicolumn{1}{c}{ Measure } \\
\hline $\begin{array}{l}\text { Strengthening the } \\
\text { stability of the financial } \\
\text { sector }\end{array}$ & $\begin{array}{l}\text { Development of guidelines, policies, instruments and standards. Co-operation } \\
\text { with the economic participants for the elaboration of an interdisciplinary appro- } \\
\text { ach related to stability risks. Development of macro-prudential guidelines dec- } \\
\text { reasing the likelihood of the development of a crisis and its negative consequ- } \\
\text { ences. }\end{array}$ \\
\hline $\begin{array}{l}\text { Monitoring financial } \\
\text { markets and industry } \\
\text { practices and structures }\end{array}$ & $\begin{array}{l}\text { Development and implementation of a forward-looking, proactive approach } \\
\text { aimed at the forecasting and management of potential system risks. Supervising } \\
\text { and monitoring individual institutions and infrastructures, with special regard } \\
\text { to those that have a significant influence on the financial system and the mac- } \\
\text { roeconomy. Development of a new supervision programme. }\end{array}$ \\
\hline Crisis prevention & $\begin{array}{l}\text { Ensuring the availability of appropriate crisis management tools, financial data } \\
\text { of appropriate quality. } \\
\text { Analysis of the role of financial stability policy in the implementation of mone- } \\
\text { tary policy. Analysis of the efficiency of the various macro-prudential policies } \\
\text { and their connection to monetary policy. Monitoring financial stability risks, } \\
\text { analysis of the relation between the financial and real economy, evaluation of } \\
\text { guideline alternatives potentially affecting system risk. }\end{array}$ \\
\hline $\begin{array}{l}\text { Scientific research on } \\
\text { finance }\end{array}$ & $\begin{array}{l}\text { Pursuing domestic and international studies on stress tests, macro-prudential } \\
\text { regulation and instruments, and other financial stability topics. Publication of } \\
\text { the results in scientific journals and conferences. }\end{array}$ \\
\hline
\end{tabular}

Source: Edited based on Fed (2014). 
The Single Supervisory Mechanism (SSM) began operation in the European Union at the end of 2014. The SSM includes the ECB and the supervisory authorities of the participating countries in one system. The objective of its foundation is to guarantee the safety and stability of the European banking system, to increase financial integration and stability, and to guarantee the consistency of supervisory work (ECB 2015).

In our interpretation, the economic stimulation measures of central banks implemented with the use of non-standard instruments are actions to be classified to the sphere of economic responsibility. Except for the interest rate changes used for inflation objectives, in connection with the economic cycles, the leading central banks did not take such steps in the approximately two decades prior to the crisis.

Although the achievement of full employment appears among the objectives of the Fed since its foundation, and the attainment of this objective is promoted by the stimulation of economic growth, achieving this objective was less prevalent in the monetary practice of the twenty years before the crisis. The Fed started the policy of quantitative easing (QE) in 2008, which it continued until the end of 2015, amended in several phases. The quantitative and the supplementing qualitative easing primarily improved the liquidity of the financial markets, but also had a favourable effect in terms of stimulating growth indirectly, by improving corporate financing conditions. In its monetary policy, the Fed also made its full employment objective a threshold value expressed in the employment rate via its forward guidance (Csortos et al. 2014). Thus, there is no doubt that the importance of the labour market within the objectives has increased. The ECB has lagged behind compared to the Fed. After the initial easing, it considered austerity measures, and only from autumn 2014 did it introduce a non-standard measure that was aimed at economic stimulus, also in an indirect manner. The delay made the recovery from the recession more difficult, while the social requirement in the European Union that the monetary authority should also support growth has increased more and more. The participants of the market interpreted the asset purchase programme, which started in Q4 2014 and was then expanded from the beginning of 2015, unanimously as an economic stimulus measure (Lentner et al. 2015:40). At the same time, the asset purchase programme also helped to decrease fluctuations in government securities market yields. In 2016, the ECB launched a corporate asset purchase programme, which it intends to continue at least until the end of 2017. The declared objective of secondary market asset purchase is to support reaching the inflation target and to improve the conditions of borrowing of households and companies (ECB 2017).

Thus, we can interpret the economic responsibility of central banks in such a way that central banks have to be more sensitive to the social effects of crisis phenomena. In addition to the above, we ascribe to the economic responsibilities 
of central banks the efficient, modern and undisturbed performance of the activities among its tasks. As an example, such activities include the efficient operation of payment and settlement systems, satisfying the requirements of the economic participants. Another element of economic responsibility is the efficient operation of the organisation of the central bank. This level can essentially be interpreted identically with the CSR element of business enterprises.

\subsection{Legal responsibility of central banks}

The legal responsibility of central banks differs from that of companies. Due to their unique role, the issue of legal responsibility of central banks requires a much more subtle interpretation.

In its authority responsibilities, the Magyar Nemzeti Bank performs the supervision of the financial markets and financial organisations. In this role, it also appears as a dispenser of justice. Based on the authorisation of legal regulations, the MNB itself is a creator of legal regulations. The opinion of the MNB must be requested when creating legal regulations related to its activities and the operation of the financial institutional system, and other legal regulations specified by law. Thus, in addition to compliance with legal regulations, the formation and interpretation of legal frameworks and having the legal regulations complied with are connected to the legal responsibilities of the central bank. The tasks of the MNB have been expanded from 2013 and it also operates as the supervisory organisation of financial enterprises, in addition to monetary policy. This task is aimed at performing the supervision of the system of financial intermediation, and ensuring the undisturbed, transparent and efficient operation of the system of financial intermediation. It must facilitate the prudent operation of the persons and organisations constituting a part of the system of financial intermediation. This task includes monitoring the careful exercise of rights by the owners and exploring undesirable business and economic risks. It applies preventive measures to mitigate or terminate risks which have already formed and to ensure the prudent operation of the individual financial organisations. The MNB protects the interests of users of the services provided by financial organisations in order to strengthen public confidence in the financial intermediary system. It operates a Financial Arbitration Board for the out-of-court settlement of disputed issues among consumers and financial organisations or persons (MNB Act 2013).

The MNB also played a considerable role in creating the legal regulation providing the framework for the conversion of foreign currency household loans into forint. It elaborated the rules of implementation of this conversion. In connection with this, it elaborated the settlement rules of costs found by the courts as charged unlawfully on the foreign currency household loans. 
As the repository of monetary policy, the MNB influences the demand and supply of the domestic currency. From the 1990s the central banks set almost only the objective of price stability for themselves according to the neoliberal principles, and they applied only a few instruments from the available set of instruments of monetary policy. For the implementation of objectives of wider horizon corresponding to its economic responsibility, the MNB has transformed and expanded its business and applied a set of instruments as well. Kolozsi and Hoffmann (2016) have shown that the operation of the monetary set of instruments cannot be considered simply as a technical task, since the efficiency of monetary policy is determined by the set of instruments. The operation of the set of instruments represents a system of rules transformed for the banking system. Within the legal frameworks, the reformation of the business and applied set of instruments required legal background work, and it has been mapped in legal responsibility as well.

We start the overview of the international trends of changes in the area of legal responsibility of central banks with the case of the Fed. The fundamental tasks and responsibilities of the Fed are regulated by the Federal Reserve Act, passed in 1913. As an effect of the responses to the 2008 crisis, there have been significant changes in the regulation of the American financial system (Biedermann 2012). In his speech of 17 June 2009, president Barack Obama (2009) emphasised that the reason for the crisis was that regulation did not prevent the abuses and culture of irresponsibility, and that fundamental reform was necessary in order to restore confidence. The objectives of the Dodd-Frank Wall Street Reform and Consumer Protection Act, passed in 2010: "facilitating the financial stability of the United States, improving the accountability and transparency of the financial system, terminating the phenomenon of "too large to fail", protecting the American taxpayers by terminating capital injections, and protecting consumers from the abuses widespread in the financial sector..." ${ }^{\prime 1}$. One of the fundamental changes affecting the Fed is that the maintenance of financial stability has been added to its objectives. Moreover, on the basis of the Act, the Fed performs not only the supervision of bank holding companies, but also the supervision of "non-bank" financial institutions, and develops and publishes its recommendations for enhanced prudential requirements vis-à-vis such institutions. In the case of inappropriate supervisory body measures, the Fed is entitled to take action in the case of "non-bank" financial institutions as well (Székely 2012). The importance of the supervisory authority function is emphasised by Kecskés and Halász (2013): The requirement of finding the persons responsible often arose during the crisis. The political situation was often criticised, saying that it created too mild rules in accordance with interests of the business lobby. Although strict reforms were introduced in the United States in 2002, the strict rules themselves are not capable of guaranteeing the long-term predictable

\footnotetext{
${ }^{1}$ Lentner et al. (2015:42) presents the provisions of the Dodd-Frank Act 2010 this way.
} 
operation of the economy. This is because ensuring strict and effective compliance with the rules is essential for this.

Lentner, Szegedi and Tatay (2015:41) presented in detail the fundamental tasks of the European Central Banking System, which were regulated by the Statute approved in 2012 (ECB 2012). The independence of the ECB was laid down in the institutional framework conditions about the uniform monetary policy (the Treaty and the Statute). The ECB is entitled to pass decrees of obligatory force if such are necessary for the performance of the tasks of the European System of Central Banks (ESCB), and in the other specific cases indicated in the legal regulations made by the EU Council. In the subject of scope and execution of EU legal regulations related to the prudential supervision of credit institutions and the stability of the financial system, the ECB can provide advice to the Council, the Commission or the authorities of the member states with competence, and these can consult with the ECB (ECB 2012).

We can interpret the other elements of legal responsibility of the ECB within the framework of the single supervisory mechanism, started at the end of 2014. The $E C B$, as an independent EU institution, performs its supervisory function connected to banking supervision by taking into account the European interests in such a way that it establishes a uniform approach in connection with the supervision of daily level, it implements co-ordinated supervisory steps and corrective measures; moreover, it ensures the consistent application of the decrees and supervisory guidelines. The ECB, together with the national supervisions, is jointly responsible for the efficient and consistent operation of the single supervisory mechanism. Its jurisdiction includes supervisory revision, conducting on-site inspections and other inquiries, and issuing and revoking bank licences. Its task is the examination of the purchase and sales activity of the banks related to controlling stake, ensuring compliance with the prudential rules of the EU, and the establishment of a higher capital requirement, a so-called buffer, in order to avoid incidental financial risks (ECB 2014b).

\subsection{Ethical responsibility of central banks}

The ethical responsibility of central banks goes beyond the performance of the tasks stipulated in the legal regulations. This responsibility, undertaken voluntarily and going beyond the legal regulations, may be manifested towards those involved in several ways. It can be stated generally that the authenticity, independence and accountability of the central bank are important. Opinions on the factors determining the confidence in the central bank are divided. According to a study using questionnaires, this is connected to professionalism and independence, and not to transparent operation (Kril et al. 2016). On the other hand, a recent comprehensive study has shown that transparency contributes favourably to decreasing uncertainty (Naszódi et al. 2016). 
Building on its previous traditions, the MNB rephrased its strategy of social responsibility, which has changed significantly since 2013. Ethical values have received an emphasised role in this. Independence, responsibility and endeavour for the common good are fundamental values of the MNB. Strengthening public confidence and genuine and transparent operation are considered as its important tasks. As another area of ethical responsibility, the MNB has indicated strengthening financial consumer protection as an objective. Within the framework of this, it pays increased attention to the legality and honest nature of the relationship between financial service providers and customers. All of these efforts support the strengthening of confidence in the financial system (MNB 2014).

The publications of the MNB provide information to the participants in the economy. The decisions and operations of the central bank have become more transparent as a result of these publications. Moreover, they also increase well-informedness in financial processes. At the Spanish central bank, transparency appears as an outstanding value, whose purpose is to support obtaining public information and to promote the accountability of the public sector (Banco de España 2017a).

The MNB provides support for its employees for starting a family and developing a healthy lifestyle. To implement equal treatment, it has announced the basic principle of "equal salary for equal work". It strives for environmental consciousness in the course of its operation (MNB 2014 b). Responsibility for the employees is also prominent at the Danish National Bank, for example they pay attention to diversity according to gender, age and seniority, the education and development of the employees, and a healthy workplace. Moreover, the bank organises career evenings and provides PhD scholarships for replacement (Danmarks Nationalbank 2017a).

The system of values of the Fed also includes ethical values, in addition to performance values (Fed 2014). The pillars of this are accountability, integrity and taking into account independent points of view. Accountability means that the Board of Governors of the Fed are accountable and responsible vis-à-vis public opinion, the government of the US and the financial community. According to the expression of integrity, the Board of Governors behaves with the public, the financial community and its employees complying with the highest norms of integrity. The point of view of independence is that the regional structure of the system supports the diversity of employees, the diversity of input sources and independent professional judgement (see in more detail: Lentner et al. 2015:42).

In a previous article, we presented the statement of the Chicago Fed, a member bank of the Fed, as follows: "corporate social responsibility is regarded as a natural extension of their service vision. They consider co-operation among the internal and external stakeholders (schools, experts, civilians, local community organisations) as important, and it is their conviction that the CSR activity results in better business 
performance and a stronger organisation. In 2011 a CSR Council was established from bank leaders, the task of this is the elaboration of the CSR strategy." (Lentner et al. 2015:42). We also presented that, in the sphere of ethical responsibility, the Fed emphasised within the framework of CSR the importance of diversity of employees, diversity of suppliers, community development and the preparation of policy studies, and environmental protection. Based on the principle of diversity of employees, they support the diversity of work environment based on the involvement of colleagues, in which the employees are respected and handled in a fair way and equal chances are provided for them. After the entry into force of the Dodd-Frank Wall Street Reform and Consumer Protection Act, passed in 2010, separate minority and women's' organisations were established. According to the principle of diversity of suppliers, they are committed to the diversity of suppliers, which includes the involvement of enterprises owned by minorities and women. The achievement of economic growth objectives is assisted with the study and support of fair access to financial services, with community development and with the preparation of policy studies. The point of view of environmental protection integrates several such business practices to the daily activity whose objective is a cleaner and healthier environment (Lentner et al. 2015).

Several ethical elements were included in the formulation of the mission of the European Central Bank. An example for this is that in the course of the implementation of the objectives of the ECB, outstanding importance is attributed to authenticity, confidence, transparency and accountability (ECB 2014a). The ECB clearly formulates its tasks and the method of executing those. It regularly informs the public about its evaluation related to the economic situation and what monetary policy can achieve and what is beyond its scope.

In order to promote price stability and based on the principle of independence, neither the ECB nor the national central banks, nor the members of their decision-making bodies can request or accept directions from the institutes and bodies of the EU, the governments of the EU member states, or from any other body. The ECB provides all the important information related to its strategy, its evaluations and political resolutions and its procedures to the public and the markets, in a transparent and timely manner. Public monetary policy and efficient communication with the public are very important. It publishes its monetary policy strategy and provides information on its regular evaluation related to economic developments. Thus, the markets can better understand the monetary policy steps, and, thanks to this, they can form their expectations more efficiently and accurately, facilitating acceleration of the necessary economic adaptation, and improving the efficiency of monetary policy. In accordance with the democratic basic principle, the $E C B$, as an independent institution endowed with a public service mission, owes responsibility and settlement to the citizens and the elected representatives of 
those. The responsibility assumed by the ECB is shown by the fact that in its regular reporting framework it exceeds its obligations stipulated in the legal regulations. Instead of the obligatory, quarterly report, the report is published each month. Moreover, members of the Governing Council inform the public about topical issues in speeches. The president and the vice-president hold regular press conferences.

The ECB regulates the behaviour expected of the members of the Governing Council in a code of conduct, with special regard to independence, conflict of interest and confidentiality. In a questionable case, the members can turn to an ethics consultant (ECB 2002). The ethical framework system related to the personnel of the ECB contains provisions related to confidentiality, the use of resources, behaviour at the workplace (i.e. the prohibition of harassment and bullying), conflicts of interest, the acceptance of gifts, private activities, procurement, fees, awards, relationships with external persons, and insider trading. Colleagues can request assistance from the ethics commissioner and can report abuses to the commissioner (ECB 2011).

Considering the practice of other central banks, the Dutch National Bank is outstanding in terms of the complex approach and institutional nature of corporate social responsibility within the organisation. Sustainability constitutes an integrated part of their mission, "Working on trust", and they place great emphasis on CSR appearing among the key obligations of the bank. The following aspects form a part of their corporate social responsibility: integrity and compliance with rules, environmental consciousness and sustainable procurement, diversity in a wider sense - which includes gender, cultural background, age, sexual orientation, physical disability, religious persuasion and qualification as well - moreover, playing a role in the various spheres of society. The bank holds a wide-ranging dialogue with its stakeholders and, in order to increase transparency, it has prepared a CSR report from 2010 on the basis of the guidelines of the Global Reporting Initiative, applied already widely in the corporate CSR area and becoming more and more widespread in the area of the public sector as well (De Nederlandsche Bank 2017).

\subsection{Philanthropic responsibility of central banks}

In our earlier article (Lentner - Szegedi - Tatay 2015), we dealt with the issue of the philanthropic responsibility of central banks in a separate chapter. By this, we mean voluntary activities that contribute to social development.

The burdens of the economic crisis highlighted the deficiencies of participants in the economy in the area of financial culture. A higher level of financial knowledge and deepening the financial culture promotes financial stability (Kovács 2015), and at the same time higher financial culture provides protection with respect to individual viewpoints as well. The role of culture influencing behaviour also carries ethical values. This is why improving information and financial culture plays an important role via education. The Magyar Nemzeti Bank places great emphasis on increasing 
the well-informedness of users of financial services and decreasing the information asymmetry (Csiszárik - Szigeti 2015). "The Magyar Nemzeti Bank considers as its objective the support of financial education, research and science, not only at the domestic, but at the international level as well. This includes, inter alia, the international publication of articles and publications of high professional level and organising conferences with the participation of domestic and international experts. It considers the following as important: playing the role of retaining, mediating and creating value; providing supports of professional nature; assisting groups in disadvantageous situations; and improving equal opportunity. It conducts charitable donations and participates in the purchase of national cultural assets (MNB 2014 b)."

The Fed promotes the organisation and completion of various studies, publications and conferences aimed at developing financial culture. In addition to financial research and conferences proper, analyses and conferences of wider, economic and social aspect appear as well, for example the research of young employees, research on the welfare of American households, and an economic mobility conference (Board of Governors of the Fed 2014). Moreover, the member banks of the Fed perform active community activities. It is the mission of the Employee Action Group of the Fed, as a good citizen, to undertake responsibility for the communities in which they work and live, assist in the life of others and strengthen the community. Their activity includes diverse programmes such as voluntary painting of houses, collecting toys for families, collecting baby clothes for expectant mothers, and cooking food for homeless shelters (Fed of Minneapolis 2014). The series of such activities include mentoring secondary schools, assisting in the reading and mathematical knowledge of primary schools' pupils, donating blood and collecting donations for AIDS, cancer and diabetic patients (Fed of New York 2014). ${ }^{2}$

In order to develop financial culture, the European Central Bank publishes popular materials, videos and games on its website, which are primarily aimed the younger generation and their teachers (ECB 2014b). Moreover, many publications are published on the website of the ECB. Developing financial culture appears prominently at the central banks of several European countries as well. The National Bank of Poland, for example, supports research and organises conferences and seminars on the role of central banks in the economy, within this, among others, about the topics of monetary policy, financial stability and the competences of central banks (Narodowy Bank Polski 2017). In connection with the topic of consumer protection, the Czech National Bank promotes the development of financial knowledge with the following: distribution of manuals and workbooks among teachers and students, and the organisation of seminars and interactive exhibitions (Czech National Bank 2017). The Danish National Bank assists economic culture with the Danish Journal of Economics scientific journal, PhD scholarships,

\footnotetext{
${ }^{2}$ See Lentner-Szegedi - Tatay 2015:44.
} 
and with an award rewarding women economists (Danmarks Nationalbank 2017b). Supporting economic research, education and university students is the objective of the Spanish National Bank as well, and humanitarian and social work, and the creation of non-profit centres also appear (Banco de España 2017b). The Dutch central bank considers itself as part of the society, which appears in community work, sponsorships, assistance, and the support of the cultural, educational and welfare sphere as well (De Nederlandsche Bank 2017).

\section{Summary}

During crisis management, the social responsibility of central banks has become more prominent. It has become a social expectation that central banks should set to themselves further objectives in addition to the maintenance of price stability. Their mandate has been expanded and maintaining financial stability has become an objective to be achieved, similarly to the implementation of the inflation target. In order to achieve the stability objective, central banks have significantly modified the set of instruments applied. Because of the modification of the declared objectives and the system of objectives, we have identified the changes occurring in the practice of market regulation of central banks in the system of framework of social responsibility primarily among the sphere of economic and legal responsibility.

In the system of framework of social responsibility, the ethical dimension serves the more efficient operation of the central banks, better corresponding to the requirements of the age, in addition to the legal frameworks. The philanthropic dimension assists in more efficient communication, strengthens the financial culture of the society, and thus enhances financial stability.

Central banks can play a significant role in maintaining the confidence in the banking system and the economy, which may be promoted by the approach of social responsibility adjusted to the characteristics of central banks. With appropriate adaptation, the economic, legal, ethical and philanthropic expectations applied in the corporate model of CSR can be interpreted for central banks as well. The social responsibility of central banks is peculiar, since these banks were established decidedly for the benefit of the common good; they are organisations promoting the achievement of specific economic policy objectives and performing state authority tasks as well. As an effect of the economic crisis, it is evident that the social responsibility of central banks has increased. They have to be sensitive to the social impacts of economic processes and play a role in ensuring that the irresponsibility of some participants of the financial sector cannot cause a significant utilisation of public funds, a recession in the real economy and social tensions. 


\section{References}

Ábel, I. - Csortos, O. - Lehmann, K. - Madarász, A. - Szalai, Z. (2014): Inflation targeting in the light of lessons from the financial crisis. Financial and Economic Review. November: 35-56.

Ábel, I. - Lehmann, K. - Tapaszti, A. (2016): Controversial handling of money and banks in macroeconomics. Financial and Economic Review, 15(2): 33-58.

Akerlof, G. - Schiller, R. (2011): Animal spirits. Corvina, Budapest.

Banco de España (2017b): Transparency. http://www.bde.es/bde/en/secciones/sobreelbanco/Transparencia/ Downloaded: 01 March 2017.

Banco de España (2017b): Cultural and social work. http://www.bde.es/bde/en/secciones/ sobreelbanco/Transparencia/Informacion_econ/Atenciones_benef/Atenciones_ cult_21239a5c48b0a41.html Downloaded: 01 March 2017.

Biedermann, Zs. (2012): History of American financial regulation. Pénzügyi Szemle 3: 337-354.

Board of Governors of the Fed (2014): Community Development. http://www.Federalreserve. gov/communitydev/default.htm Downloaded: 13 December 2014.

Braun, B. (2016): Speaking to the people? Money, trust, and central bank legitimacy in the age of quantitative easing. Review of International Political Economy, Volume 23: 1064-1092. https://doi.org/10.1080/09692290.2016.1252415.

Carroll, A.B. (1979): A Three-Dimensional Model of Corporate Performance. Academy of Management Review, Vol. 4., No. 4: 497-505. https://doi.org/10.2307/257850.

Carroll, A.B. (1991): The Pyramid of Corporate Social Responsibility: Toward the Moral Management of Organizational Stakeholders. Business Horizons, July-August.

Carroll, A.B. (2015a): The State of CSR in 2015 and Beyond. In: Global Compact (2015) Global Compact International Yearbook 2015. Macondo Publishing GmbH: 10-13.

Carroll, A.B. (2015b): Corporate social responsibility: The centerpiece of competing and complementary frameworks. Organizational Dynamics, 44: 87-96. https://doi. org/10.1016/j.orgdyn.2015.02.002.

Carroll, A.B., - Shabana, K.M. (2010): The business case for corporate social responsibility: A review of concepts, research and practice. International Journal of Management Reviews, 12(1): 85-105.

Chikán, A. (2003): Business economics. Aula Kiadó, Budapest.

Csiszárik-Kocsir, Á. - Szigeti, C. (2015): Financial culture of youth in Hungary. In: Kratochvíl, R. - Vopava, J. - Douda, V. (ed.): Proceedings of the 4th MAC 2015. Prague, Czech Republic, 20.02.2015-21.02.2015 Prague. MAC Prague consulting. 
Csortos, O. - Lehmann, K. - Szalai, Z. (2014): Theoretical considerations and practical experiences of forward guidance. MNB Bulletin, July 2014, pp. 45-55.

Czech National Bank (2017): Consumer protection. http://www.cnb.cz/en/consumer/index. html Downloaded: 01 March 2017.

Dalhsrud, A. (2008): How corporate social responsibility is defined: an analysis of 37 definitions. Corporate Social Responsibility and Environmental Management, 15(1): 1-13. https://doi.org/10.1002/csr.132.

Danmarks Nationalbank (2017a): Careers at Danmarks Nationalbank. http://www. nationalbanken.dk/en/career/Pages/Default.aspx Downloaded: 01 March 2017.

Danmarks Nationalbank (2017b): Danmarks Nationalbank and economic research. http:// www.nationalbanken.dk/en/about_danmarks_nationalbank/DN_and_economic_research/ Pages/default.aspx Downloaded: 01 March 2017.

De Nederlandsche Bank (2017): Corporate Social Responsibility. https://www.dnb.nl/ en/about-dnb/organisation/maatschappelijk-verantwoord-ondernemen/index.jsp Downloaded: 01 March 2017.

De Nederlandsche Bank (2016): Central Banks Keep Finger on Money Creation Pulse. DNBulletin 19 August; accessed at www.dnb.nl/en/news/news-and-archive/ dnbulletin-2015/dnb325255.jsp, 3 September 2016.

Dodd, E.M. Jr. (1932): For Whom are Corporate Managers Trustees? Harvard Law Review 45(7): 1145-1163. https://doi.org/10.2307/1331697.

Dodd-Frank Act (2010): https://www.sec.gov/about/laws/wallstreetreform-cpa.pdf Downloaded: 14 December 2014.

ECB (2002): Code of Conduct for the Members of the Governing Council https://www.ecb. europa.eu/ecb/legal/pdf/hu_mou_on_code_of_conduct_consolidated_f.pdf Downloaded: 14 December 2014.

ECB (2011): Part of the conditions of employment of the personnel of the ECB containing the ethical framework system. https://www.ecb.europa.eu/ecb/legal/pdf/ c_04020110209hu00130017.pdf Downloaded: 14 December 2014.

ECB (2012): Protocol about the Statute of the European System of Central Banks and the European Central Bank. Official Journal of the European Union, 26.10.2012 https:// www.ecb.europa.eu/ecb/legal/pdf/c_32620121026hu_protocol_4.pdf Downloaded: 14 December 2014.

ECB (2014a): Mission of the European Central Bank. https://www.ecb.europa.eu/ecb/orga/ escb/ecb-mission/html/index.hu.html Downloaded: 12 November 2014. 
ECB (2014b): Popular materials. https://www.ecb.europa.eu/ecb/educational/html/index. hu.html Downloaded: 14 December 2014.

ECB (2015): Single Supervisory Mechanism. https://www.bankingsupervision.europa.eu/ about/thessm/html/index.hu.html Downloaded: 05 January 2015.

ECB (2017): Resolution No. 2017/103 of the European Central Bank https://www.ecb.europa.eu/ecb/legal/pdf/celex_32017d0004_hu_txt.pdf Downloaded: 20 February 2017.

Evan, W.M. - Freeman, R.E. (1996): Stakeholder theory of the modern enterprise: Kantian capitalism. In: Boda, Zs. - Radácsi, L. (1996). Corporate ethics. BKE Vezetőképző Intézet, Budapest: 93-108.

Federal Reserve Bank (2014): Annual Performance Plan. http://www.Federalreserve.gov/ publications/gpra/files/2014-gpra-performance-plan.pdf Downloaded: 10 December 2014.

Federal Reserve Bank of Chicago (2016): Corporate Social Responsibility. https://www. chicagoFed.org/utilities/about-us/csr/index Downloaded: 10 December 2016.

Federal Reserve Bank of Minneapolis (2014): Community Involvement. https://www. minneapolisfed.org/about/careers/community-involvement Downloaded: 14 December 2014.

Federal Reserve Bank of New York (2014): Community Involvement. http://www.newyorkFed. org/careers/comminvolve.html. Downloaded: 14 December 2014.

Jakab, Z. - Kumhof, M. (2015): Banks are not intermediaries of loanable funds - and why it matters. Bank of England Working Paper, No. 529. https://doi.org/10.2139/ssrn.2612050.

Kahn, A. (2016): Central Bank Governance and the Role of Nonfinancial Risk Management. IMF Working Paper. February 2016. https://doi.org/10.5089/9781498376051.001.

Kecskés, A. - Halász, V. (2013): Stock Corporations: A Guide to Initial Public Offerings, Corporate Governance and Hostile Takeovers. HVG-ORAC - LexisNexis, Budapest-Vienna, p. 191.

Kerekes, S. (2009): Foundations of environmental economics. Aula Kiadó.

Kolozsi, P.P. - Hoffmann, M. (2016): Reduction of external vulnerability with monetary policy tools. Pénzügyi Szemle 2016/1: 9-34.

Kril, Z. - Leiser, D. - Spivak, A. (2016): What Determines the Credibility of the Central Bank of Israel in the Public Eye? The International Journal of Central Banking, March 2016. http:// www.ijcb.org/journal/ijcb16q1a3.pdf Downloaded: 10 December 2016. 
Kovács, L. (2015): Research of financial culture and our current tasks. Economy and Finance, Volume 2: pp. 79-88.

Kurucz, E. - Colbert, B. - Wheeler, D. (2008): The business case for corporate social responsibility. In: A. Crane, A. McWilliams, D. Matten, J. Moon, \& D. Siegel (eds.), The Oxford handbook of corporate social responsibility. Oxford University Press: 83-112.

Lagarde, C. (2014): Economic Inclusion and Financial Integrity-an Address to the Conference on Inclusive Capitalism. https://www.imf.org/external/np/speeches/2014/052714.htm Downloaded: 07 December 2014.

Lentner, Cs. - Szegedi, K. - Tatay, T. (2015): Social responsibility of central banks. Vezetéstudomány, 46(9-10): 35-47.

Margolis, J.D. - Elfenbein, H.A. - Walsh, J.P. (2009): Does it Pay to Be Good...And Does it Matter? A Meta-Analysis of the Relationship between Corporate Social and Financial Performance. (March 1). http://dx.doi.org/10.2139/ssrn.1866371.

Matolcsy, Gy. (2015): Balance and growth. KAIROSZ Könyvkiadó, Budapest, p. 644.

MNB (2014): Independence and Responsibility. Statute of the Magyar Nemzeti Bank, May. https://www.mnb.hu/letoltes/a-magyar-nemzeti-bank-alapokmanya-1.pdf. Downloaded: 13 December 2014.

MNB (2014): Social responsibility strategy of the Magyar Nemzeti Bank. https://www.mnb.hu/letoltes/mnb-tarsadalmi-spread-low-1.pdf Downloaded: 11 December 2016.

MNB Act (2013): Act on the Magyar Nemzeti Bank (2013). https://www.mnb.hu/a-jegybank/ kozerdeku-adatok/tevekenysegre-mukodesre-vonatkozo-adatok/a-szerv-alaptevekenysegefeladata-es-hataskore/jegybanktorveny Downloaded: 14 December 2014.

Naszódi, A. - Csávás, Cs. - Erhart, Sz. - Felcser, D. (2016): Which Aspects of Central Bank Transparency Matter? A Comprehensive Analysis of the Effect of Transparency of Survey Forecasts. The International Journal of Central Banking, December 2016. http://www.ijcb. org/journal/ijcb16q4a4.pdf Downloaded: 11 December 2016.

Neményi, J. (2012): Effect of the financial crisis on the regulation of central banks. Competition and regulation. MTA KRTK Közgazdaság-tudományi Intézet. May: 167-219. Narodowy Bank Polski (2017): Research \& Conferences. http://www.nbp.pl/homen. aspx?f=/badania/konferencje_en.htm Downloaded: 01 March 2017.

Obama, B. (2009): Remarks by the President on 21st Century Financial Regulatory Reform. The White House Office of the Press Secretary, June 17, 2009.

Pesuth, T. (2016): Redefining the role of the central bank. Pénzügyi Szemle, 2016/1 pp. 35-49. 
Rangan, V.K. - Chase, L. - Karim, S. (2015): The Truth About CSR. Harvard Business Review, January-February: 40-49.

Sági, J. (2010): Discretionality of Monetary Policy. In: Radványi, T. (ed.) Money and society: Essays from the scientific workshop of the Financial and Accounting Department of the Budapest Business School. Budapest: Financial and Accounting Department of the Budapest Business School: 59-62.

Shirakawa, M. (2010): Revisiting the philosophy behind central bank policy. Speech by Mr Masaaki Shirakawa, Governor of the Bank of Japan, at the Economic Club of New York, New York, 22 April. http://www.bis.org/review/r100427b.pdf Downloaded: 10 December 2016.

Schoen, E.J. (2016): The 2007-2009 Financial Crisis: An Erosion of Ethics: A Case Study. Journal of Business Ethics, February.

Smith, A. (1759): The Theory of Moral Sentiments. http://www.ibiblio.org/ml/libri/s/SmithA_ MoralSentiments_p.pdf Downloaded: 11 April 2012.

Sunstein, R.C. - Thaler, R.H. (2011): Nudge. Better decisions about health, money and happiness - after the financial crisis. Budapest, Manager Könyvkiadó és Könyvkereskedő Kft, p. 264.

Szczerbowicz, U. (2015): The ECB Unconventional Monetary Policies: Have They Lowered Market Borrowing Costs for Banks and Governments? The International Journal of Central Banking, December 2015. http://www.ijcb.org/journal/ijcb15q5a3.pdf Downloaded: 11 December 2016.

Szegedi, K. (2014): Possibilities of Corporate Social Responsibility. In: Berényi, L. (Ed.) (2014): Management Challenges in the 21st Century. LAP LAMBERT Academic Publishing.

Székely, A. (2012): Regulatory response steps to the crisis in the United States. Financial and Economic Review, 3: 230-253. http://www.bankszovetseg.hu/wp-content/ uploads/2012/10/230-253-szekely1.pdf Downloaded: 13 December 2012.

Trichet, J.C. (2010): Central banking in uncertain times: conviction and responsibility. Speech by Jean-Claude Trichet, President of the ECB, at the symposium on "Macroeconomic challenges: the decade ahead", Jackson Hole, Wyoming, 27 August 2010. http://www. ecb.europa.eu/press/key/date/2010/html/sp100827.en.html Downloaded: 10 December 2014.

Yellen, J.L. (2014): Remarks at the Panel Discussion on "Shaping the Future of the Macroeconomic Policy Mix" At the "Central Banking: The Way Forward?", International Symposium of the Banque de France, Paris, France, November 7. http://www. Federalreserve.gov/newsevents/speech/yellen20141107a.htm Downloaded: 07 December 2014. 